Check for updates

The BMJ

kabbasi@bmi.com Follow Kamran on Twitter@KamranAbbasi Cite this as: $B M / 2022 ; 376: 0398$ http://dx.doi.org/10.1136/bmj.0398 Published: 17 February 2022

\title{
Why the new normal might be the old normal-but worse
}

\section{Kamran Abbasi editor in chief}

When Russia named its SARS-CoV-2 vaccine Sputnik $\mathrm{V}$ we entered a space race in all but name. Russia was first to announce the efficacy of its vaccine-without supporting data (doi:10.1136/bmj.0321). ${ }^{1}$ Russia was first to announce successful phase III trials-without supporting data. Despite trial results now being published, requests to access the data are being denied (doi:10.1136/bmj.n1108). ${ }^{2}$ Russia is far from alone in this deviation from good practice, but even the Russian public isn't persuaded of the value of its country's own vaccine, with vaccination rates running below 50\%. Indeed, Russia has had a disastrous pandemic, possibly the worst in the world by measures of excess deaths.

That regulators still approve drugs without wide access to raw data remains a preventable scandal. That the US Food and Drug Administration accelerated the approval of aducanumab, a monoclonal antibody targeting amyloid $\beta$ for treatment of Alzheimer's disease, in defiance of the recommendations of its own scientific advisory committee, shows how regulators have grown too close to industry (doi:10.1136/bmj-2021-069780). ${ }^{3}$ This is nothing new, but why is it allowed to continue, to the detriment of citizens? For its part, the European Medicines Agency has refused to authorise the drug. Proponents of complicity theory will be unsurprised that Biogen, the drug's manufacturer, looks set to appeal an entirely sensible regulatory decision.

Corporate greed remains prominent elsewhere, with the involvement of gambling companies in decisions on how to prevent harm from gambling. These tend to ignore the industry's "sophisticated marketing of highly addictive products," such as the blanket sponsorship of professional football. Experts from the London School of Hygiene and Tropical Medicine argue that this year's promised update of the UK's 2005 Gambling Act must be reframed to prevent gambling harms rather than mitigate them (doi:10.1136/bmj.0248). ${ }^{4}$

The burden of these politico-industrial manoeuvres continues to fall on people who are disadvantaged. The same effect is seen in new US data showing increased rates of mental illness after covid-19 when compared with contemporary and historical controls (doi:10.1136/bmj-2021-068993,

doi:10.1136/bmj.0326). ${ }^{56}$ With increased pressure on mental health services and ongoing staff shortages (doi:10.1136/bmj.0350), ${ }^{7}$ BMJ Careers has launched a new UK jobs board for mental health professionals (https://healthjobs.bmj.com).

England's proposed health and care bill raises the question of the ongoing role of the private sector in future service delivery, although it may not be the route to privatisation that some fear. Nonetheless, worries about excessive ministerial control and the absence of clear strategies to tackle workforce shortages, social care provision, and inequalities-as reinforced by a damning new report on the influence of race on health outcomes

(doi:10.1136/bmj.0382) ${ }^{8}$-suggest that the UK government's proposals are light in important areas and with regard to persistent problems

(doi:10.1136/bmj.0361). ${ }^{9}$

One conclusion is that promises to build back better or build back fairer are empty, especially when the haste to end all restrictions, including abandoning covid surveillance (doi:10.1136/bmj.0376), ${ }^{10}$ is widely condemned as ill informed and reckless

(doi:10.1136/bmj.0383). ${ }^{11}$ We're reconstructing the same flawed society that failed to respond effectively to SARS-CoV-2 and continues to fail on climate action. The answers may lie in new approaches to incentivise sustainable corporate behaviour, reduce the rich world's consumption, and, most interestingly, to encourage "degrowth" (doi:10.1136/bmj-2021o68126)..$^{12}$ Doctors and other health professionals are stronger than they think, with influence stretching from citizens to politicians (doi:10.1136/bmj.0246). ${ }^{13}$ The challenge is to ensure that the "new normal” isn't simply the "old normal" but with even more damaging consequences.

Loseva P. Data and distrust hamper Russia's vaccination programme. BM 2022;376:0321. doi: 10.1136/bmj.0321 pmid: 35149521

2 van Tulleken C. Covid-19: Sputnik vaccine rockets, thanks to Lancet boost. BMJ 2021;373:n1108. doi: 10.1136/bmj.n1108 pmid: 33958384

3 Lythgoe MP, Jenei K, Prasad V. Regulatory decisions diverge over aducanumab for Alzheimer's disease. BMJ 2022;376:e069780. doi: 10.1136/bmj-2021-069780 pmid: 35091420

4 van Schalkwyk MCl, Blythe J, McKee M, Petticrew M. Gambling Act review. BMJ 2022;376:0248. doi: 10.1136/bmj.0248 pmid: 35105539

5 Xie Y, Xu E, Al-Aly Z. Risks of mental health outcomes in people with covid-19: cohort study. BMJ2022;376:e068993.

6 Weich S. Mental health after covid-19. BM/2022;376:0326.

7 lacobucci G. Covid-19: Staff absences are continuing to stretch NHS hospitals, say leaders. BMJ2022;376:0350. doi: 10.1136/bmj.0350 pmid: 35149517

8 Wise J. Racial health inequity is stark and requires concerted action, says review. BMJ 2022;376:0382. doi: 10.1136/bmj.0382 pmid: 35165092

9 Moberly T. Ten things you need to know about the Health and Care Bill. BMJ 2022;376:0361.

10 Salisbury H. Helen Salisbury: Why numbers matter. BMJ 2022;376:0376. doi: 10.1136/bmj.0376 pmid: 35165119

11 Waters A. Covid-19: Show us evidence for lifting restrictions, doctors tell Johnson. BMJ 2022;376:0383doi: 10.1136/bmj.0383.

12 Labonté R. A post-covid economy for health: from the great reset to build back differently. BMJ2022;376:e068126.

doi: 10.1136/bmj-2021-068126 pmid: 35078773

13 Oliver D. David Oliver: Central diktats won't help more patients leave local hospitals. BMJ2022;376:0246. doi: 10.1136/bmj.0246 pmid: 35140069 